\title{
The complement system of the goat: Haemolytic assays and isolation of major proteins
}

\author{
Isabel Moreno-Indias ${ }^{1,2}$, Alister W Dodds ${ }^{2}$, Anastasio Argüello ${ }^{1 *}$, Noemi Castro ${ }^{1}$ and Robert B Sim²
}

\begin{abstract}
Background: The aim of the present study was to develop a haemolytic assay for the study of the complement system in dairy goats (Capra aegagrus hircus) and to characterize the major goat complement system proteins.

Results: The commonly used sheep erythrocyte sensitized with rabbit antibodies were not sensitive to lysis by goat serum, but the combination of human red blood cells (RBC) plus rabbit antibodies was the best option found for goat complement assay. A buffer based on HEPES instead of the classical veronal (barbitone) was developed. Three proteins were isolated: factor $\mathrm{H}, \mathrm{Clq}$ and $\mathrm{C} 3$ and these were compared with the corresponding human proteins. A novel affinity chromatography technique was developed for isolation of factor $\mathrm{H}$.
\end{abstract}

Conclusions: Human RBC plus rabbit antibodies were a suitable option for haemolytic assays. The isolated proteins are similar to the human counterparts.

Keywords: Goat, Complement system, C3, C1q, Factor H

\section{Background}

Complement is a central component of the innate immune system which is involved in host defense against infectious agents [1]. It has three physiological activities: defending against pyogenic bacterial infection, bridging innate and adaptive immunity, and disposing of immune complexes and the products of inflammatory injury [2]. The complement system may be activated by three different pathways: the classical, the lectin and the alternative pathway [3]. The classical pathway is activated by binding of the $\mathrm{C} 1 \mathrm{q}$ protein to targets, such as Gram negative bacteria, immunoglobulins bound to microorganisms or altered host components, such as amyloids or apoptotic cells; the alternative pathway may be directly activated by microorganisms and also by IgG immune complexes. The lectin pathway is activated by MBL (mannose-binding lectin) bound to carbohydrates present on the surface of microbes [4]. The lectin pathway of complement can also be activated via L-ficolin [5], H-ficolin [6], M-ficolin [7] and by the recentlydescribed Collectin 11 [8]. The complement system in mammals has been well described, particularly in human

\footnotetext{
* Correspondence: aarguello@dpat.ulpgc.es

${ }^{1}$ Animal Science Department, Universidad de las Palmas de Gran Canaria,

Arucas, Las Palmas 35413, Spain

Full list of author information is available at the end of the article
}

and mice. Some other vertebrate species have been examined at various levels of detail (e.g. chimpanzee, dog, horse, sheep, guinea-pig, pig, cattle, chicken and some fish), and it is clear their complement systems are very similar [1]. In vertebrate studied, the complement system consists of about 35-40 proteins commonly associated with blood plasma and blood cells, but found generally at lower concentration in other secretions of the body [9], like lymph, colostrum or milk [3].

In farm animals, the complement system has been studied principally in cows [10-12], although there are some studies in other ruminants, like buffalos [9]. There is scanty research papers on goats.

Some studies on conditions for assaying haemolytic complement of goat sera [13] and in particular of the alternative complement pathway [14] have been published. Other published work on goat complement includes studies of infection with some parasites like Trypanosoma evansi [15] or with the estimation of the molecular size of the $\mathrm{C} 1$ complex [16], purification of C1q [17] or mapping of MHC-linked complement genes [18]. In theses studies, $\mathrm{C} 2$ and $\mathrm{C} 4$ were found to be MHC-linked, as in humans.

Recently, Castro et al. [19] demonstrated a relationship between nutrition and complement system activity in goat kids during the first two months of life. More 
knowledge about the complement system in goats is necessary to understand this relationship in depth.

The aim of the present study was to develop an efficient combination of antibodies and $\mathrm{RBC}$ to provide a feasible haemolytic assay for goat serum/plasma. An additional objective was to isolate the major complement system proteins from goat plasma, in order to raise antibodies for future quantitative concentration measurements. The proteins were $\mathrm{C} 1 \mathrm{q}$, the first protein involved in the classical pathway [20], factor $H$, because of its importance in the regulation of the alternative pathway [21], and C3, the most abundant protein (at least in humans) which forms part of all three pathways [22].

\section{Results}

Figure 1 shows the tests results of goat, human and guinea pig serum/plasma against various RBC preparations. Goat plasma and serum showed completely different specificity from human and guinea pig serum. Goat plasma and serum lysed human RBC sensitized with rabbit antibodies, but human and guinea pig serum had no activity against these cells. There was also some lysis of unsensitised human erythrocytes by goat serum and plasma. In contrast, goat serum/plasma did not lyse sheep erythrocytes with any combination of antibodies (even with goat antibodies), while human and guinea pig sera did lyse these cells. Lysis of unsensitised sheep erythrocytes by human serum is due to the presence of anti-Forssman antibodies in the human serum/plasma.

It was necessary to adapt the assay to a more suitable buffer, because of the difficulty in obtaining sodium barbital (veronal) in some countries. HEPES was tried instead of barbitone. Figure 2 shows the comparison of

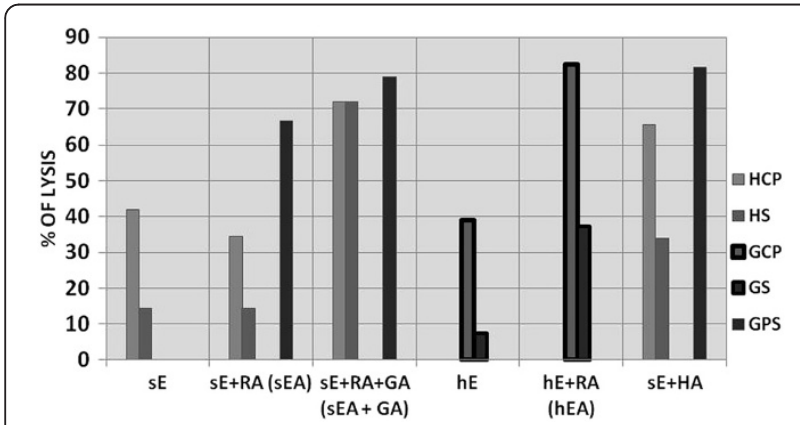

Figure 1 Lysis of different cells, with and without antibody by human, goat and guinea-pig plasma/serum (HCP and HS, GCP and GS, and GPS, respectively). Sheep (sE) and human (hE) erythrocytes were pre-coated or not with rabbit or rabbit + goat antibodies. Erythrocytes $\left(50 \mu \mathrm{l}\right.$ of $\left.10^{9} / \mathrm{ml}\right)$ in DGVB ${ }^{++}$were incubated with $100 \mu$ l of $1 / 5$ dilution of plasma/serum for 1 hour at $37^{\circ} \mathrm{C}$. Percentage of cell lysis was calculated as indicated in methods section.sE, hE: sheep and human erythrocytes without pre-coated; sEA, hEA = sheep and human pre-coated with rabbit antibodies; RA, $\mathrm{GA}, \mathrm{HA}=$ rabbit, goat and human antibodies, respectively.

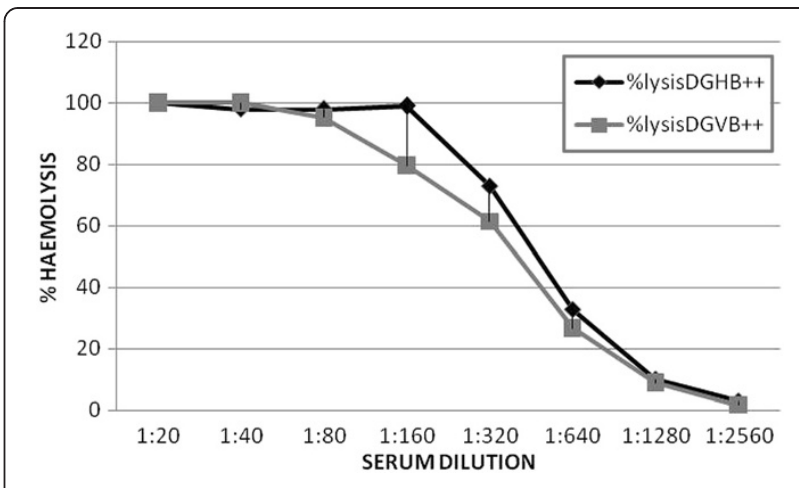

Figure 2 Comparison of HEPES (DGHB ${ }^{++}$) and Veronal $\left(\mathrm{DGVB}^{++}\right.$) buffers. Serial 2-fold dilutions of human serum were prepared in either buffer, starting at 1/20 (5\%). Dilutions (100 $\mu \mathrm{l})$ were mixed with $100 \mu \mathrm{l}$ of $10^{8} / \mathrm{ml}$ sheep EA cells, in the same buffer, and incubated for 1 hour, at $37{ }^{\circ} \mathrm{C}$. Percentage lysis was calculated as in methods.

the two buffers for an assay of human serum complement with sheep EA. Although both buffers work similarly, the titre measured was slightly higher with HEPES. Further experiences in using both buffers for goat complement showed that both are suitable for assays, but whereas $\mathrm{DGVB}^{++}$is a good buffer for long-term storage of $\mathrm{RBC}, \mathrm{DGHB}^{++}$needs to be removed and changed for another buffer to store the EA cells. A good buffer to store the cells is Alsever's Solution.

The effects of "classical" versus "alternative" pathway buffers on goat complement assay are shown in figure 3.

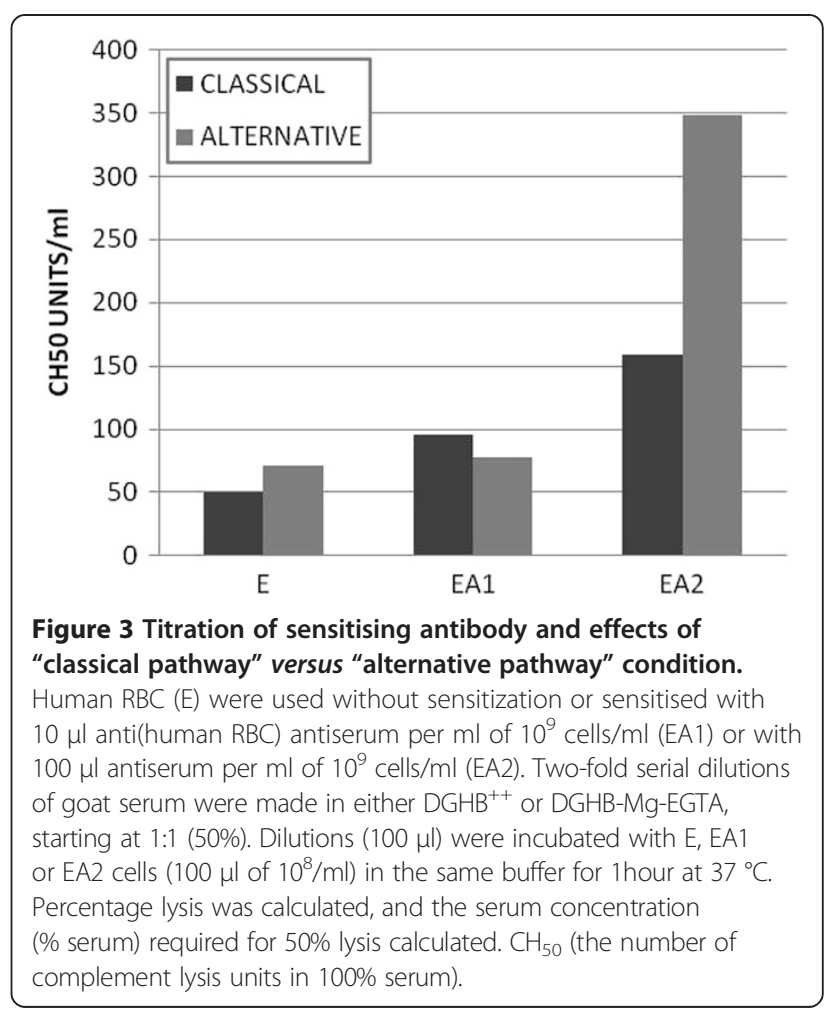


In $\mathrm{DGVB}^{++}$or $\mathrm{DGHB}^{++}$all three complement system pathways can be activated, although it would be expected that the classical pathway works at lower serum concentrations than the other pathways. In DGVB-Mg-EGTA or DGHB-Mg-EGTA only the alternative pathway can work, because the other pathways require $\mathrm{Ca}^{2+}$ (for the binding of the proteases $\mathrm{C} 1 \mathrm{r}, \mathrm{C} 1 \mathrm{~s}$ or the MASPS, to C1q, MBL or ficolins). Two different sensitising antibody concentrations are shown. When the assay was done with hE cells, goat serum showed a titre of about $5 \mathrm{CH} 50$ units in either buffer. A two-fold higher titre was obtained when the EA cells were sensitised with a low concentration of rabbit anti(human RBC) (about 80$100 \mathrm{CH} 50$ units in either buffer); however, at higher antibody concentration a higher titre was observed and in the alternative pathway buffer this titre was more pronounced than in the classical pathway buffer (350 CH50 units versus 150 units). In a separate experiment, the concentration of antibody was varied titrating the antihuman RBC, and the maximum titre response was obtained with concentrations higher than $80 \mu \mathrm{l}$ of antiserum per $\mathrm{ml}$ of cells at $10^{9} / \mathrm{ml}$ in DGHB++ (not shown).

The fact that the titre in the alternative pathway was higher than in the classical pathway, suggests that elevated concentration of antibody present on the cells seems to activate the alternative pathway. As it has been shown by Gadd and Reid [23] antigen-bound rabbit IgG activates the alternative pathway (in human serum). The antiserum used (rabbit anti-human RBC membrane) was produced with booster injections of antigen over a 6 months period, so it had mainly an IgG response. The $\mathrm{CH} 50$ values for various serum samples from different goats are shown in figure 4 . These results demonstrated

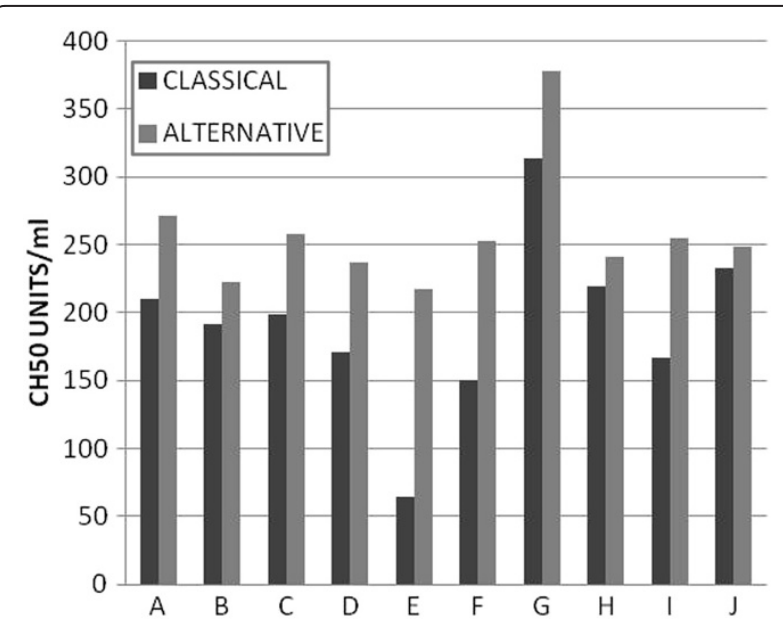

Figure 4 Comparison of multiple samples. Ten goat serum samples were assayed (as described in the legend for fig. 3) using $\mathrm{DGHB}^{++}$and DGHB-Mg-EGTA buffers, and highly sensitised EA (equivalent to EA2 in fig. 3). The titre of each sample $\mathrm{CH} 50$ units in the assay is shown for both buffer conditions. that this assay (using the maximum antibody sensitisation) is able to distinguish among different samples. The fact that the alternative pathway buffer, in all cases gave higher values than the classical pathway buffer is very interesting, and it must be studied in greater detail. A possible explanation could be the fact that the magnesium ion concentration affects the apparent titre in alternative pathway assays [24].

SDS-PAGE analysis of factor $\mathrm{H}(\mathrm{FH})$ purification is depicted in figure 5. Factor $\mathrm{H}$ was identified by its chromatographic behaviour and co-running with human $\mathrm{FH}$ on SDS-PAGE; FH forms the major symmetrical peak on the final gel filtration step. As previously observed [25], human factor $\mathrm{H}$ binds strongly to TNPderivatised BSA. As shown here, goat factor $\mathrm{H}$ also binds to TNP. This binding is of high affinity, so that high salt/denaturing buffers are required for elution of the bound protein. Factor $\mathrm{H}$, however, is resistant to denaturation, and use of urea/guanidine buffers would not be expected to cause loss of activity.

SDS-PAGE with various fractions of goat $\mathrm{C} 1 \mathrm{q}$ from the final mono-S ion exchange is shown in figure 6. The yield from purification was low, but purity was adequate. Human IgG was used as the affinity ligand, and the result confirms that goat $\mathrm{C} 1 \mathrm{q}$ does bind to human IgG, although SRBC sensitised by human IgG/IgM are not lysed by goat serum/plasma (fig 1). The Goat C1q appears similar to human C1q on SDS-PAGE. With C1q

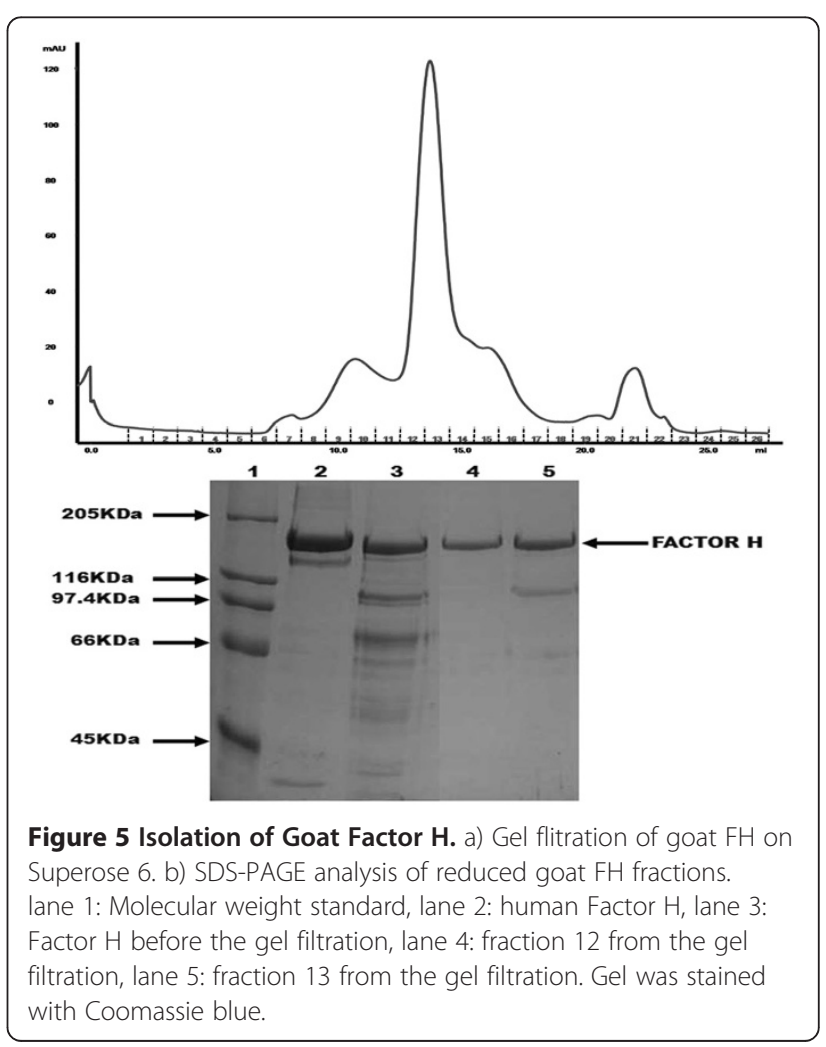




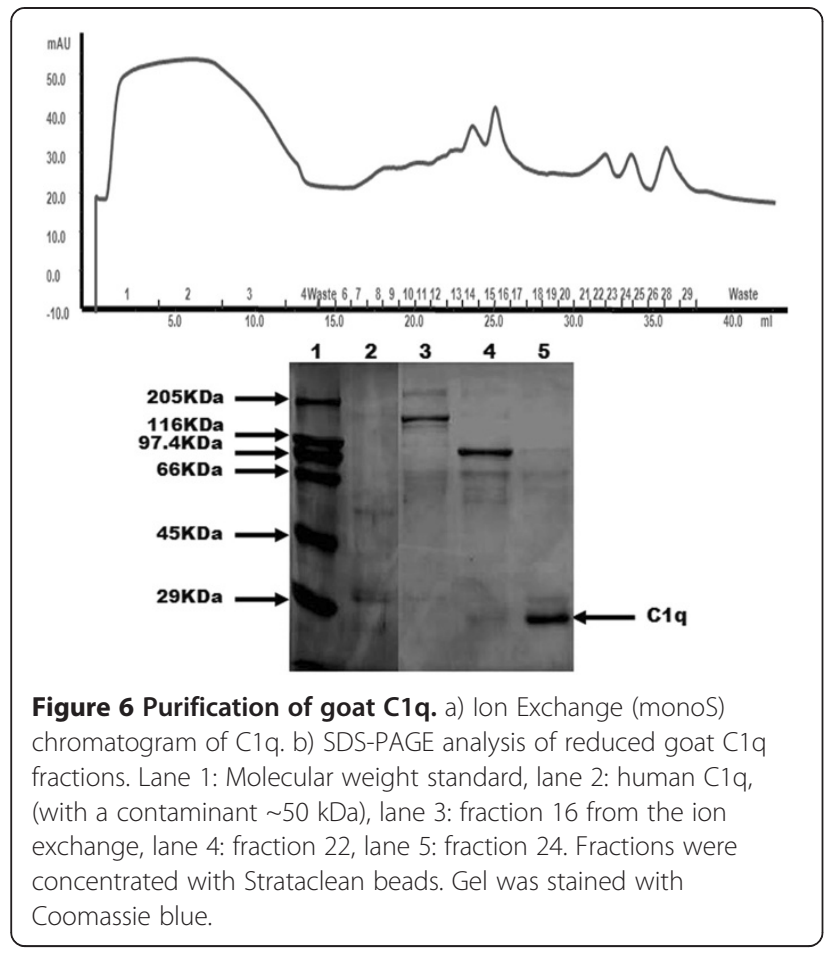

from different species, the relative elution positions of the $\mathrm{a}, \mathrm{b}$ and $\mathrm{c}$ chains may differ. In human, a doublet band at $\sim 29 \mathrm{kDa}$ represents the a and b chains, while a fainter band at $\sim 25 \mathrm{kda}$ is the c chain. The c chain aggregates in SDS-PAGE, and may also appear as faint higher bands $(50-70 \mathrm{kDa})$. For goat $\mathrm{C} 1 \mathrm{q}$, there is a fainter band at $\sim 29 \mathrm{kda}$, which may represent the $\mathrm{c}$ chain, and a strong band at $\sim 25 \mathrm{kDa}$, which most likely represents the co-running a and b chains. C1q is a basic high molecular weight glycoprotein which has two major problems in its purification: a low yield and contaminant inmunoglobulins [26], and because of its low yield, it was necessary to concentrate samples for SDS-PAGE analysis with Strataclean beads (Stratagene).

SDS-PAGE analysis of fractions of the last gel filtration of the purification of $\mathrm{C} 3$ is shown in figure 7. Goat C3 was of good purity although it could be contaminated with C5. C3 and C5 are homologues of the same mol. wt., and in human and rodent, they tend to co-run in chromatographic procedures [27]. The minor band under the C3 alpha chain, marked C3 alpha', may represent either the alpha' chain of $\mathrm{C} 3 \mathrm{~b}$, or the alpha chain of $\mathrm{C} 5$.

\section{Discussion}

Sheep erythrocytes do not work in the assay of complement in Majorera goat samples in agreement with the results of Venugopal et al. [14], who found negligible activity using sheep and cattle erythrocytes, working with goats of undefined breed. This was not observed

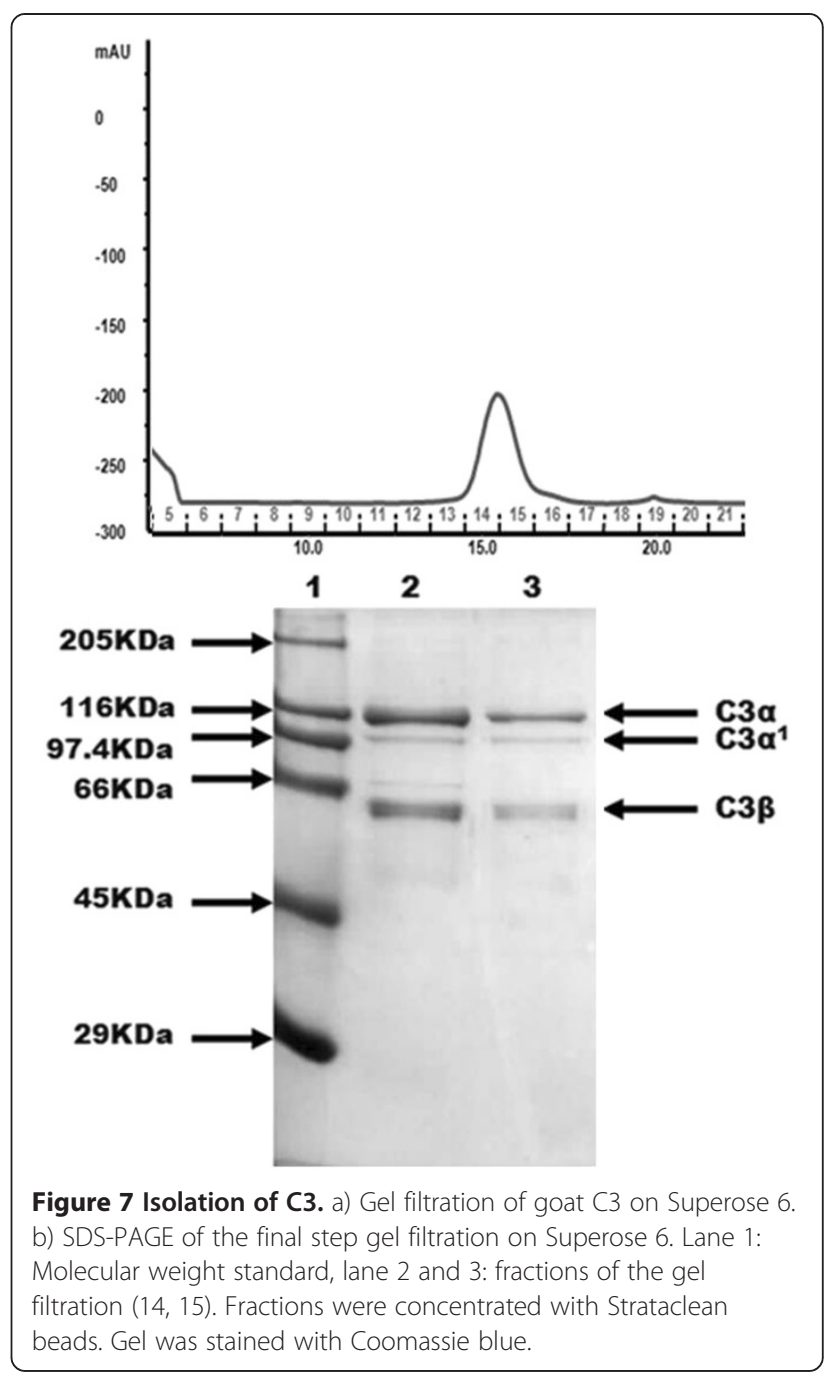

previously by Olaho-Mukani et al. [15] who used sheep $\mathrm{RBC}$ with good results with African goats. Oyekan and Barta [13] showed that the best results for goat complement (breed not stated) were obtained with guinea pig or pig erythrocytes sensitized with goat or cattle antibodies, They also observed lysis with unsensitised rabbit and horse erythrocytes, and low but detectable lysis with sensitised sheep erythrocytes. Noguchi and Bronfenbrenner [28] did observe that human RBC were usable for testing goat complement. Castro and co-workers [19] used also Majorera goats for their experiment with rabbit erythrocytes without sensitizing.

The resistance to lysis of sheep RBC may be because sheep complement regulatory proteins (equivalent to CD59 or DAF) are compatible with goat complement proteins. These types of protein protect host cells from autologous complement attack [29]. These results could be due to a structural similarity between the interaction sites of proteins of both species. For a long time, bovine complement was considered to be nonhemolytic, 
because it was not able to lyse sheep erythrocytes [30]. However, in Holstein Bull serum, Chang-Fa et al. [31] did not find any relationship between phylogenetic proximity of erythrocyte species to cattle and the degree of hemolysis, attributing this response to the content of the serum of high levels of natural antibodies against RBC of various species. The highest was against guinea pigs and the lowest against cows, sheep, goats and pigs. So, it is possible that in goats something similar happens.

In general, as expected the sensitivity of the assay was improved by sensitization of the erythrocytes with specific antibodies, which enhances the activation of the classical pathway (IgG and IgM) and the alternative pathway (IgG). Buffer was changed because it is difficult to get veronal buffer in some laboratories. Veronal (sodium barbiturate) is the most widely reagent used to measure the activity of the complement system $[4,13-15,32]$, but other buffers have been used to measure the activity. For example Castro et al. [19] used PBS and saline to measure the total complement system activity in kid goat serum although to measure the alternative pathway it was necessary to use the normal EGTA-Mggelatin-Veronal buffer. HEPES is a good buffering agent for maintaining physiological $\mathrm{pH}$. The major problem was the storage of $\mathrm{RBC}$ in this buffer, which was much poorer than in $\mathrm{DGVB}^{++}$. For this reason is better to use another buffer, such as Alsever's solution for storage, to wash the erythrocytes frequently and to minimize as much as possible the storage period in HEPES. The high values for titres in the alternative pathway buffer were unexpected. The "classical pathway" buffer allows activation of all three pathways, while the "alternative pathway" buffer allows only the alternative pathway to work.

It was expected a lower titre for the alternative pathway as the classical pathway usually dominates the activity of the complement system in most species, e.g. classical pathway activity is detectable in more dilute serum than is lectin or alternative pathway activity [4]. The same titre value in the two buffer systems would suggest that the activity of the complement system is due to the alternative pathway, but in our work a higher value was observed in the alternative pathway buffer. These results are consistent with previous findings showing that goats have potent alternative pathway activation as was suggested by Venugopal et al. [14], and supported by Castro et al. [19] and Rodríguez et al. [33] who, working with Majorera goat kids, found that the only pathway used was the alternative. The alternative pathway is continually activated at a low controlled rate but amplified by the surface of invading microorganisms [34]. The environment where the goats live is controlled, e.g., nutrition, hygiene or health are supervised by the University staff, and it is thought that microbes that activate the alternative pathway are less pathogenic than those which do not [35], so that mutation causing loss of the classical pathway (e.g. loss of C4) might not be a survival factor for these goats.

The higher titre found in the alternative pathway buffer could be due to the higher $\mathrm{Mg}^{2+}$ concentration; Fishelson and Müller-Eberhard [24], showed that raising the $\mathrm{Mg}^{2+}$ concentration increased the alternative pathway titre. It would be interesting to probe with different of $\mathrm{Mg}^{2+}$ concentrations, Venugopal et al. [14] found that higher levels of $\mathrm{Mg}^{2+}$ ions $(>5 \mathrm{mM})$ had an inhibitory effect on the caprine alternative pathway. Matheswaran et al. [9], working with buffalo colostrum and with concentrations from 4 to $20 \mathrm{mM}$ of $\mathrm{Mg}^{2+}$, found no differences, although they chose the concentration of $4 \mathrm{mM}$ as optimum.

The apparent absence of classical pathway could be due to a failure in some component of the classical pathway cascade, possibly a $\mathrm{C} 4$ deficiency, or perhaps just because some components were in low concentration, as it occurs in bovine milk with C1q [36].

Factor $\mathrm{H}$ controls the activity of the alternative pathway C3/C5 convertase by competing with factor B for C3b binding and by serving as a cofactor for factor I, to mediate the cleavage of C3b to iC3b [29]. Many procedures have been used to purify factor $\mathrm{H}$. In humans, Sim and Discipio [21] used five chromatography steps to isolate Factor $\mathrm{H}$ : first two steps of polyethyleneglycol (PEG) precipitation were used, continuing with L-Lysine- Sepharose 4B chromatography, DEAE-Sephadex A-50 chromatography, Sepharose 6B gel filtration, Hydroxyl-Apatite-Ultrogel chromatography and finally a DEAE-Sepharose CL-6B chromatography. Nakano et al. [37] used a shorter procedure to isolate rabbit factor $\mathrm{H}$ using various precipitation steps with PEG then three steps of chromatography on DEAE Sephacel; and a further two steps of Sephadex G200 gel filtration. Mhatre and Aston [38] used a first step of PEG precipitation then three steps of chromatography: DEAE-Sephacel, CM-Sephadex A-50 and Sephadex G-200 to isolate bovine Factor H. More recently, Factor $\mathrm{H}$ has been isolated from porcine seminal plasma by using a Q-Sepharose column then a Matrex Gel Red A column, finishing with an FPLC Superdex 200 column [39]. The method used in the present study seems to be easier and faster and with good results as shown in figure 5. It has three steps: TNP-BSA- Sepharose, protein G Hi-Trap and Superose 6. Binding of human factorH to TNP-BSA had been observed before [24], but this is the first report where this ligand for affinity purification is used.

C1q has a critical function in host defence and clearance of immune complexes, and for this reason it is desirable to study goat $\mathrm{C} 1 \mathrm{q}$ in more depth. Lin et al. [17] used 2 different methods for the purification of goat C1q: in one, the procedure was based on two successive 
precipitation steps at low ionic strength, and followed by an additional purification through a Sepharose CL-6B gel filtration column; and in the other, they used a twostep chromatography, with a BioRex 70 and a Sepharose CL-6B columns. C1q is a protein which has a high affinity for heparin and IgG, so McKay [40] used these characteristics to make a two-step affinity chromatography procedure to purify $\mathrm{C} 1 \mathrm{q}$ from various species (human, rat, rabbit, dog and sheep). Pohl et al. [41] isolated C1q using a three-step purification procedure: precipitation from plasma, affinity chromatography with a rabbit IgGSepharose column and cleaning up with a rabbit antihuman IgG-Sepharose affinity column. Sasaki et al. [42] working with guinea pig serum, combined precipitation with chelating agents, CM-cellulose and Superose 6, and Stemmer and Loos [43] used a simple and rapid procedure for the purification of $\mathrm{C} 1 \mathrm{q}$ from human, guinea pig and mouse serum, with euglobulin precipitation, chromatography on Superose 6B, then Mono S ion exchange.

To establish a simple method to isolate goat complement $\mathrm{C} 1 \mathrm{q}$, previous reports were used as references. As several procedures used immobilised IgG, non-immune human IgG-Sepharose was chosen to begin, followed by a Protein G Hi-trap column to remove contaminant human IgG, ending with ion exchange chromatography on MonoQ and MonoS to remove all the contaminants. The yield was very low, possibly because the concentration of this protein in goats is low, or because human IgG may not be a very high affinity ligand. As noted above, it is possible that $\mathrm{C} 1 \mathrm{q}$ is present in low concentration, in that there was very low apparent classical pathway complement activation.

Although little is known about the goat complement genome, only goat C9 and Factor B have been sequenced as far as we know, a goat genome project is in progress [44] and probably in the next years the sequences of the complement system proteins will be known, so that we will be able to compare the sequences with humans or other species and learn about potential structural or functional differences.

Complement C3 may be the most studied protein of the complement system, due to its abundance and importance in all three pathways. It has been studied and isolated from many species and usually C3 has been isolated in a similar way with a first step of differential precipitation with PEG, continuing with column chromatography (e.g. Giclas et al. [45] for rabbit and Gresham et al. [46] for human). Storm et al. [47] isolated porcine C3 with PEG precipitation and DEAE-Sephacel chromatography, ending with a size exclusion chromatography with Sepharose CL-6B and a hydroxylapatite chromatography to remove the contaminants. Basta and Hammer [48], established a two step protocol to isolate C3: PEG precipitation and fast protein liquid chromatography
(FPLC) Mono Q ion exchange chromatography, using human and guinea pig. A procedure used in fishes like the spotted wolfish, in which a PEG precipitation, continued by a MonoQ and a Superose 12 exclusion chromatography was described by Abelseth et al., [49]. Most recent procedures for the isolation of this protein have been based on the work of Dodds [50] which was used in the present study and consists of PEG precipitation, and 2-3 ion-exchange steps.

There has been no report of C3 isolation from goats, but in other ruminants, C3 has been purified from cows [51] using a four step protocol: polyethylene glycol precipitation and chromatography on DEAE-Sephadex A-50, CM-Sephadex A-50 and Sephacryl S-200. In camels, the same procedure was followed by Ouma et al. [52]. In the present study the protocol has been simplified to three steps based on a Q Sepharose FF, followed by a MonoQ and a Superose 6.

\section{Conclusions}

The alternative pathway of the goat complement system is the predominant pathway. Human RBC plus rabbit antibodies are the best option for haemolytic assays. HEPES buffer is a good alternative for laboratories where Veronal buffer is difficult to acquire. The main proteins Factor $\mathrm{H}, \mathrm{C} 1 \mathrm{q}$ and $\mathrm{C} 3$ in goats were isolated and are similar to the human counterparts.

\section{Materials and methods}

This study was performed in accordance with adequate ethical standards and animal care and was approved by the Ethics and Animal Welfare Committee of the University of Las Palmas de Gran Canaria, Las Palmas, Spain.

\section{Plasma/serum}

Blood samples from Majorera goats were obtained at Las Palmas de Gran Canaria University (Animal Science Department). Health status of the animals was suitable. Animals were vaccinated against Staphylococcus aureus and their feeding regime was based on corn, soy 66, dehydrated lucerne, dehydrated beetroot, wheat straw and a vitamin-mineral corrector, in accordance with the guidelines issued by L'Institut de Recherche Agronomique [53].

Blood was taken from the jugular vein into a tube with buffered sodium citrate $0.106 \mathrm{M}(100 \mathrm{ml}$ of this buffer to $1 \mathrm{~L}$ of blood) and centrifuged for 10 minutes at $2,130 \mathrm{~g}$ and $4{ }^{\circ} \mathrm{C}$. Plasma was then frozen at $-80{ }^{\circ} \mathrm{C}$ and transported on dry ice to Oxford University where laboratory determinations were performed. The initial sample was citrated-plasma, so it was converted to serum by adding $\mathrm{CaCl}_{2}$ to a final concentration of $20 \mathrm{mM}$, incubating for 20 minutes at $37{ }^{\circ} \mathrm{C}$ and centrifuging for 15 minutes at $2,500 \mathrm{~g}$. 


\section{Haemolytic assays \\ Buffers}

Initial haemolytic assays were based on reagents described by Whaley and North [25]. DGVB ${ }^{++}$buffer (Dextrose Gelatin Veronal Buffer, with $\mathrm{Ca}^{++}$and $\mathrm{Mg}^{++}$: $2.5 \mathrm{mM}$ sodium barbital, $71 \mathrm{mM} \mathrm{NaCl}, 0.15 \mathrm{mM} \mathrm{CaCl}_{2}$, $0.5 \mathrm{mM} \mathrm{MgCl}_{2}, 2.5 \%(\mathrm{w} / \mathrm{v})$ glucose, $0.1 \%(\mathrm{w} / \mathrm{v})$ gelatin, $\mathrm{pH}$ 7.4) was used for the classical pathway and DGVB-MgEGTA buffer (2.1 mM sodium barbital, $59 \mathrm{mM} \mathrm{NaCl}$, $7.0 \mathrm{mM} \mathrm{MgCl}_{2}, 2.08 \%(\mathrm{w} / \mathrm{v})$ glucose, $0.08 \%(\mathrm{w} / \mathrm{v})$ gelatin, $10 \mathrm{mM}$ EGTA, pH 7.4) for the alternative pathway.

In later analyses the $\mathrm{DGVB}^{++}$buffer was changed for $\mathrm{DGHB}^{++}$buffer in which $5 \mathrm{mM}$ HEPES replaced $2.5 \mathrm{mM}$ sodium barbital and the DGVB-Mg-EGTA was changed for DGHB-Mg-EGTA, in which 4.2 mM HEPES replaced $2.1 \mathrm{mM}$ sodium barbital

\section{Preparation of antibody-sensitised erythrocytes (EA)}

EA cells were prepared as described by Whaley and North [25]. Sheep erythrocytes (sE) were from sheep blood in Alsevers (TCS Biosciences Ltd., Buckinghamshire, UK) and rabbit antibody was haemolysin (SigmaAldrich, Poole, UK). sE and sEA were prepared as described by Whaley and North [25]. To prepare sheep erythrocytes with goat antibodies, $(\mathrm{sEA}+\mathrm{GA})$, goat-antirabbit IgG antibodies were added to sEA. sEA $(0.5 \mathrm{ml}$ at $\left.10^{9} / \mathrm{ml}\right)$ were incubated with $0.5 \mathrm{ml}(1: 1000)$ goat antirabbit IgG (Sigma-Aldrich, Poole, UK) for 1 hour at RT. After that, two washes in $\mathrm{DGVB}^{++}$were done. Human erythrocytes (hE) were prepared from blood collected from healthy volunteers, taken with EDTA as anticoagulant and rabbit anti-(human RBC membrane) antiserum was from the MRC Immunochemistry Unit. Blood samples were centrifuged (10 $\mathrm{min}, 2500 \mathrm{~g}$ ) and plasma was removed and stored for later assays. hE were washed in PBS- $0.5 \mathrm{mM}$ EDTA and then 2 times in $\mathrm{DGHB}^{++}$until the supernatant was clear. Then the concentration of hE was adjusted to $10^{9} / \mathrm{ml}$ as for $\mathrm{sE}$. To prepare hEA cells, $10 \mathrm{ml}$ of hE cells were incubated with $100 \mu \mathrm{l}$ of rabbit anti-(human RBC membrane) antiserum heat-treated for 30 minutes at $56{ }^{\circ} \mathrm{C}$. After that, 2 washes in $\mathrm{DGHB}^{++}$ were done and cell number adjusted to $10^{9} / \mathrm{ml}$. sE were also sensitised with human antibodies (anti-Forssman). Two $\mathrm{ml}$ of $\mathrm{sE}$ at a concentration of $10^{9} / \mathrm{ml}$ and $1 \mathrm{ml}$ of human EDTA-plasma were mixed and incubated for $30 \mathrm{~min}$ at $37{ }^{\circ} \mathrm{C}$. Then cells were washed with $\mathrm{DGVB}^{++}$ and adjusted again to $10^{9} / \mathrm{ml}$.

\section{Establishing a haemolytic assay for goat serum}

Tests were done with different combinations of erythrocytes and antibodies to establish what system was most sensitive to lysis by goat complement. These combinations were: sheep RBC, sheep RBC plus rabbit antibodies (haemolysin, containing IgM and IgG), sheep RBC plus rabbit haemolysin plus goat IgG anti-rabbit IgG (Sigma), human $\mathrm{RBC}$, human $\mathrm{RBC}$ plus rabbit antihuman red blood cell membrane (IgM and IgG) and sheep RBC plus human antibodies (IgM and IgG anti-Forssman). In initial tests, $50 \mu \mathrm{l}$ of cells or antibody-sensitized cells at $10^{9} / \mathrm{ml}$ was incubated with $100 \mu \mathrm{L}$ of serum or plasma diluted to $1 / 5$ in $\mathrm{DGVB}^{++}$for $1 \mathrm{hr}$ at $37{ }^{\circ} \mathrm{C}$ before calculation of lysis as described below.

\section{Haemolytic titration assay}

A typical classical pathway ( $\mathrm{CH} 50)$ test was done using $100 \mu \mathrm{l}$ of goat serum serial 2 -fold dilutions (starting at $50 \%$ serum, serially diluting 10 times) in $\mathrm{DGVB}^{++}$, mixed with $100 \mu \mathrm{l}$ of $10^{8} / \mathrm{ml}$ EA cells in $\mathrm{DGVB}^{++}$. E cells were also used as controls in place of EA. Cells and sera were incubated for $1 \mathrm{hr}$ at $37{ }^{\circ} \mathrm{C}$, centrifuged $(10 \mathrm{~min}$, $2,500 \mathrm{~g}$ ) and the OD 405 of the supernatant measured to assess lysis. Percentage complement-dependent lysis was calculated relative to cells lysed in water (100\% lysis) and cells incubated with buffer only ( $0 \%$ complementdependent lysis). Alternative pathway (AP50) assays were done in the same way, but with DGVB-Mg-EGTA as buffer. In later analyses the assay buffers were $\mathrm{DGHB}^{++}$ or DGHB-Mg-EGTA. To calculate CH50 or AP50, \% lysis was plotted against \% serum and the serum dilution giving $50 \%$ lysis was determined. The $\mathrm{CH} 50$ or AP50 was calculated as $100 /(\%$ serum causing $50 \%$ lysis $)$ x 10 and is expressed as units per $\mathrm{ml}$.

\section{Factor $\mathrm{H}$ isolation}

For the isolation of factor $\mathrm{H}$ a commercial serum (caprine serum, Sera Lab International Ltd) was used. It was diluted 1:1 with water to reduce ionic strength. For the isolation of the factor $\mathrm{H}, 200 \mathrm{ml}$ of the goat serum dilution was mixed with $20 \mathrm{ml}$ of TNP-BSA-Sepharose, prepared as indicated by Arnold et al. [54], for one hour in a slow rotary stirrer at $4{ }^{\circ} \mathrm{C}$. The resin was thoroughly washed with HEPES buffer (10 mM HEPES, $60 \mathrm{mM}$ $\mathrm{NaCl}, 0.5 \mathrm{mM}$ EDTA pH 7.4). This affinity column binds mainly Factor H, IgG and IgM [54]. Three different solvents were assessed for elution of the bound protein: urea buffer (10 mM MES, $6 \mathrm{M}$ urea $\mathrm{pH} 6.0$ ); $2 \mathrm{M} \mathrm{NaCl}$; and $6 \mathrm{M}$ guanidine- $\mathrm{HCl}$ buffer $(6 \mathrm{M}$ guanidine- $\mathrm{HCl}$, $10 \mathrm{mM}$ Tris, $100 \mathrm{mM}$ Na phosphate $\mathrm{pH}$ 8.0-8.2). The resin was placed in a column and washed successively with the three solvents and fractions of $4 \mathrm{ml}$ were collected. Elution was monitored by reading OD 280. Fractions containing protein were dialysed against PBS-0.05 mM EDTA. The best eluants were the $2 \mathrm{M}$ $\mathrm{NaCl}$ and Guanidine buffer, according to the amount of eluted protein measured at OD280 and analysis by SDSPAGE. Fractions eluted in these solvents were pooled together and passed thought a $1 \mathrm{ml}$ Protein G "Hi-Trap" column (GE Healthcare) to remove IgG. The column 
was washed with PBS- $0.05 \mathrm{M}$ EDTA and the IgG was eluted with Glycine/ $\mathrm{HCl}$ buffer $(0.2 \mathrm{M}$ glycine adjusted to $\mathrm{pH} 2.2$ with $\mathrm{HCl}$ ). To purify Factor $\mathrm{H}$ further gel filtration was used with a Superose $610 / 300$ GL column (GE Healthcare), using filtered PBS-5 mM EDTA as running buffer. Purification was monitored by SDS-PAGE analysis using human factor $\mathrm{H}$ as standard.

\section{C1q isolation}

The diluted goat serum which passed through TNPBSA-Sepharose was used to prepare C1q. For the isolation of subcomponent $\mathrm{C} 1 \mathrm{q}, 25 \mathrm{ml}$ of non-immune human IgG-Sepharose prepared as indicated by Sim et al. [55] was added to $200 \mathrm{ml}$ of the diluted goat serum and incubated for 1 hour close to $0{ }^{\circ} \mathrm{C}$ on a slow rotary stirrer. The IgG-Sepharose was rapidly and thoroughly washed on a scintered glass filter with ice-cold PBS$5 \mathrm{mM}$ EDTA and bound proteins were eluted with icecold CAPS buffer (50 mM CAPS, $1 \mathrm{M} \mathrm{NaCl}, 5 \mathrm{mM}$ EDTA, $\mathrm{pH} 11.0$ to 11.2 ). The $\mathrm{pH}$ of the eluted fractions was reduced to 7.5 by adding a buffering substance (0.5 $\left.\mathrm{M} \mathrm{NaH}_{2} \mathrm{PO} 4\right)$. The eluted protein (without dialysis) was passed through a $\mathrm{Hi}$-Trap protein $\mathrm{G}$ column to remove IgG. The protein solution was then dialysed against $10 \mathrm{mM}$ HEPES, $10 \mathrm{mM} \mathrm{NaCl} \mathrm{pH7.4,} \mathrm{and} \mathrm{run} \mathrm{on}$ a MonoQ 5/5 column (GE Healthcare) equilibrated in the same buffer. $\mathrm{C} 1 \mathrm{q}$ does not bind to the column, but contaminants were removed. The run-through fraction containing $\mathrm{C} 1 \mathrm{q}$ was finally dialysed against $230 \mathrm{mM}$ $\mathrm{Na}$-acetate at $\mathrm{pH} 5.2$ and run on a monoS $5 / 5$ column (GE Healthcare) in the same buffer. $\mathrm{C} 1 \mathrm{q}$ was eluted in a linear gradient of $\mathrm{NaCl}$ concentration $(0-400 \mathrm{mM} \mathrm{NaCl}$ in the acetate buffer). Purification was monitored by SDS-PAGE analysis using human C1q as standard.

\section{C3 isolation}

For isolation of protein C3, citrated plasma obtained from a Majorera male goat of the farm of the Las Palmas de Gran Canaria University was used. C3 was isolated as described for human C3 by Dodds [50] with minor modifications. Three chromatography steps were necessary: an anion exchange chromatography with a $\mathrm{Hi}$ Load 16/10 Q Sepharose FF column (GE Healthcare) with the buffers $20 \mathrm{mM}$ HEPES, $50 \mathrm{mM}$ e-aminocaproic acid, $5 \mathrm{mM}$ EDTA pH 7.4, plus $0.2 \mathrm{mM}$ PMSF, and the same buffer plus $1 \mathrm{M} \mathrm{NaCl}$; an anion exchange chromatography with a MonoQ HR 5/5 column with the same buffers; and finally, a gel filtration chromatography with a Superose 6 10/300 GL column in PBS-5 mM EDTA. Each step was analyzed with SDS-PAGE (9\% (wt/vol) acrylamide).

\section{SDS-PAGE}

SDS-PAGE was performed using the method of Laemmli [56]. Sample buffer, sample preparation and staining with
Coomassie Blue were as described by Fairbanks et al. [57]. All samples were run under reducing conditions.

Human C3 and human Factor H, used as standards in the gels, were purified as described in Dodds [50] and Sim et al. [55]. Human C1q was prepared as described by Tan et al. [58]. The molecular weight standard used was from Sigma.

\section{Acknowledgement}

This work was supported by grant AGL 2006-08444/GAN from the Spanish Government. Thanks to Oxford University and the staff of the lab of E Sim and RB Sim. Thanks to Dr Anne Jakel for taking human blood samples.

\section{Author details}

${ }^{1}$ Animal Science Department, Universidad de las Palmas de Gran Canaria, Arucas, Las Palmas 35413, Spain. ${ }^{2}$ MRC Immunochemistry Unit, Department of Biochemistry, University of Oxford, South Parks Road, Oxford OX1 3QU, UK.

\section{Authors' contributions}

IM carried out all the experimental work and manuscript preparation. AD coordinated and supervised C3 assays and manuscript preparation. AA and NC supervised and advised on scientific content of the manuscript and critical revision of the text. RBS designed, coordinated and supervised the study and manuscript preparation. All authors read and approved the final manuscript.

Received: 30 August 2011 Accepted: 26 June 2012 Published: 26 June 2012

\section{References}

1. Mayilyan KR, Kang YH, Dodds AW, Sim RB: The complement system in innate immunity. In Innate Immunity of Plants, Animals and Humans. Edited by Heine H. Berlín: Springer-Verlag Berlin Heidelberg; 2008:219-236. 21.

2. Walport MJ: Complement: first of two parts. N Engl J Med 2001, 344:1058-1066.

3. Rainard P: The complement in milk and defense of the bovine mammary gland against infections. Vet Res 2003, 34:647-670.

4. Seelen MA, Roos A, Wieslander J, Mollnes TE, Sjoholm AG, Wurzner R, Loos M, Tedesco F, Sim RB, Garred P, Alexopoulos E, Turner MW, Daha MR: Functional analysis of the classical, alternative, and MBL pathways of the complement system: standardization and validation of a simple ELISA. J Immunol Methods 2005, 296:187-198.

5. Matsushita M, Endo Y, Fujita T: Cutting edge: complement-activating complex of ficolin and mannose-binding lectin-associated serine protease. J Immunol 2000, 164:2281-2284.

6. Matsushita M, Kuraya M, Hamasaki N, Tsujimura M, Shiraki H, Fujita T: Activation of the lectin complement pathway by H-ficolin (Hakata antigen). J Immunol 2002, 168:3502-3506.

7. Frederiksen PD, Thiel S, Larsen CB, Jensenius JC: M-ficolin, an innate immune defence molecule, binds patterns of acetyl groups and activates complement. Scand J Immunol 2005, 62:462-473.

8. Hansen S, Selman L, Palaniyar N, Ziegler K, Brandt J, Kliem A, Jonasson M, Skjoedt MO, Nielsen O, Hartshorn K, Jørgensen TJ, Skjødt K, Holmskov U: Collectin 11 (CL-11, CL-K1) is a MASP-1/3-associated plasma collectin with microbial-binding activity. J Immunol 2010, 185:6096-6104.

9. Matheswaran K, Raj GD, Nachimuthu K: Demonstration of Alternative and Classical Complement Pathway Activity in Colostrum from Buffalo (Bubalus bubalis). Vet Res Commun 2003, 27:445-452.

10. Booth NA, Campbell RD, Fothergill JE: The purification and characterization of bovine $\mathrm{C} 4$, the fourth component of complement. Biochem J 1979, 177:959-965.

11. Campbell RD, Booth NA, Fothergill JE: Purification and Characterization of Subcomponent C1q of the first Component of Bovine Complement. Biochem J 1979, 177:531-540.

12. Mueller R, Carroll EJ, Panico L: Hemolytic complement titers and complement C3 levels in endotoxin-induced mastitis. Am J Vet Res 1983 44:1442-1445 
13. Oyekan PP, Barta O: Hemolytic assay for goat (caprine) and swine (porcine) complement. Vet Immunol Immunopathol 1980, 1:317-328.

14. Venugopal G, Ram GC, Bansal MP: Determination of optimal in vitro conditions for caprine alternative complement pathway assay. Vet Immunol Immunopathol 1992, 32:359-364.

15. Olaho-Mukani W, Munyua WK, Njogu AR: Haemolytic complement and class-specific antibody levels in goats during infection with Trypanosoma evansi and after treatment with diminazene aceturate. Small Rum Res 1996, 22:241-247.

16. Borsos T, Rapp HJ: Estimation of molecular size of complement components by Sephadex chromatography. J Immunol 1965, 94:510-513.

17. Lin TM, Halbert SP, Cort R, Blaschke J: An enzyme-linked immunoassay for circulating immune complexes using solid phase goat C1q. J Immunol Methods 1983, 63:187-205.

18. Cameron PU, Tabarias H, Pulendran B, Robinson W, Dawkins RL: Conservation of the central MHC g Anome: PFGE maping and RFLP analysis of complement, HSP70, and TNF genes in the goat. Immunogenetics 1990, 31:253-264.

19. Castro N, Acosta F, Niño T, Vivas J, Quesada E, Capote J, Argüello A: The effects of diet and age on serum complement system activity in goat kids. Livest Sci 2008, 119:102-109.

20. Ghai R, Waters P, Roumenina LT, Gadjeva M, Kojouharova MS: Reid KB, Sim RB, Kishore U: C1q and its growing family. Immunobiology 2007, 212:253-266.

21. Sim RB, Discipio RG: Purification and structural studies on the complement-system control protein $\beta_{1} \mathrm{H}$ (Factor H). Biochemical J 1982, 205:285-293.

22. Scott JD, Fothergill JE: A general method for affinity purification of complement component C3b using factor H-Sepharose. Biochem J 1982 205:575-580.

23. Gadd KJ, Reid KB: Importance of the integrity of the inter-heavy-chain disulphide bond of rabbit lgG in the activation of the alternative pathway of human complement by the $F\left(a b^{\prime}\right) 2$ region of rabbit lgG antibody in immune aggregates. Immunology 1981, 42:75-82.

24. Fishelson Z, Müller-Eberhard HJ: C3 convertase of the human alternative pathway of complement: modulation of enzyme activity and stability by mouse monoclonal antibodies to Bb. Eur J Immunol 1987, 17:303-304.

25. Whaley K, North J: Haemolytic assays for whole complement activity and individual components. In Complement: a Practical Approach. chapter 2. Edited by Dodds AW, Sim RB. Oxford, UK: IRL Press; 1997:19-47.

26. Rhen M, Linder E: Three step purification of C1q by DNA precipitation, ion exchange and lectin affinity chromatography. J Clin/ Pathol 1982, 35:1114-1117.

27. O'Rear LD Ross, G.D: Isolation and Purification of C3 from Human Plasma. Currents Protocols in Immunology. 10:13.3.1-13.3.16

28. Noguchi H, Bromfenbrenner J: The comparative merits of various complements and amboceptors in the serum diagnosis of syphilis. $J$ Exp Med 1911, 13:78-91.

29. Morley BJ, Walport MJ: The Complement Facstbook. Great Britain: Factsbook series. Academic Press; 2000.

30. Rice CE, Crowson CN: The interchangeability of the complement components of different animal species in the hemolysis of sheep erythrocytes sensitized with rabbit amboceptor. J Immunol 1950, 65:201-210.

31. Chang-Fa W, Yun-Dong G, Hong-Mei W, Shao-Hua Y, Yan Z, Jian-Bin L, Ming-Hai H, Ji-Feng $\mathrm{Z}$ : Characterization of alternative complement hemolytic pathway activity in Holstein bull serum. Acta Zool Sinica 2006, 52:698-705.

32. Wouters D, Brouwer MC, Daha MR, Hack CE: Studies on the haemolytic activity of circulating C1q-C3/C4 complexes. Mol Immunol 2008, 45:1893-1899.

33. Rodríguez C, Castro N, Capote J, Morales-Delanuez A, Moreno-Indias I, Sánchez-Macías D, Argüello A: Effect of colostrum immunoglobulin concentration on immunity in Majorera goat kids. J Dairy Sci 2009, 92:1696-1701.

34. Tabel H: Alternative pathway of complement in ruminants: role in infection. Vet Immunol Immunopathol 1996, 54:117-121.

35. Saulsbury FT, Winkelstein JA: Activation of the alternative complement pathway by L-phase variants of gram-positive bacteria. Infect Immun 1979, 23:711-716.
36. Rainard P, Poultrel B: Generation of complement fragment $\mathrm{C} 5 \mathrm{a}$ in milk is variable among cows. J Dairy Sci 2000, 83:945-951.

37. Nakano Y, Tobe T, Matsuda T, Sakamoto T, Tomita M: Isolation and characterization of rabbit factor $\mathrm{H}$ of the alternative complement pathway. J Biochem 1984, 95:1469-1475.

38. Mhatre A, Aston WP: Isolation of bovine complement factor $\mathrm{H}$. Vet Immunol Immunopathol 1988, 14:357-375.

39. Sakaue T, Takeuchi K, Maeda T, Yamamoto Y, Nishi K, Ohkubo I: Factor H in porcine seminal plasma protects sperm against complement attack in genital tracts. J Biol Chem 2010, 285:2184-2192.

40. MCKay EJ: A simple two-step procedure for the purification of plasma C1q from different animal species. Immunol Lett 1981, 3:303-308.

41. Pohl DA, Gibbons JJ, Tsai CT, Roodman ST: Isolation and purification of human C1q from plasma. J Immunol Methods 1980, 36:13-27.

42. Sasaki $T$, Ueda $M$, Yonemas $K$ : The subcomponent $\mathrm{C} 1 \mathrm{q}$ of the first component of guinea pig complement: Purification and characterization. $\mathrm{J}$ Immunol Methods 1982, 48:121-131.

43. Stemmer F, Loos M: Purification and characterization of human, guinea pig and mouse $\mathrm{C} 1 \mathrm{q}$ by fast protein liquid chromatography (FPLC). $\mathrm{J}$ Immunol Methods 1984, 71:9-16.

44. Mapping the Caprine Genome, Institut National the la Reserche Agronomique; http://locus.jouy.inra.fr/cgi-bin/lgbc/mapping/common/ intro2.pl?BASE=goat.

45. Giclas PC, Keeling PJ, Henson PM: Isolation and characterization of the third and fifth components of rabbit complement. Mol Immunol 1981 18:113-123.

46. Gresham HD, Matthews DF, Griffin FM: Isolation of human complement component C3 from small volumes of plasma. Anal Biochem 1986 154:454-459.

47. Storm KE, Arturson G, Nilsson UR: Purification and characterization of porcine C3. Studies of the biologically active protein and its split products. Vet Immunol Immunopathol 1992, 34:47-61.

48. Basta M, Hammer $\mathrm{CH}$ : A rapid FPLC method for purification of the third component of human and guinea pig complement. J Immunol Meth 1992, 142:39-44.

49. Abelseth TK, Stensva K, Espelid S, Nygaard R, Ellingsen T, Bøgwald J, Dalmo RA: The spotted wolffish (Anarhichas minor Olafsen) complement component C3: isolation, characterisation and tissue distribution. Fish Shellfish Immunol 2003, 15:13-27.

50. Dodds AW: Small-scale preparation of complement components C3 and C4. Meth Enzymol 1993, 223:46-61.

51. Menger M, Aston WP: Isolation and characterization of the third component of bovine complement. Vet Immunol Immunopathol 1985, 10:317-331.

52. Ouma JO, Olaho-Mukani W, Mutani A, Wishitemi BEL, Guya SO: Dromedary complement (C3): Purification, characterisation and quantitation of its levels during experimental Trypanosoma evansi infection in camels. J Camel Prac Res 1998, 5:213-218.

53. Jarrige J: Alimentación de bovinos, ovinos y caprinos. Madrid, Spain: Mund Prensa; 1990.

54. Arnold JN, Wormald MR, Suter DM, Radcliffe CM, Harvey DJ, Dwek RA, $\operatorname{Sim}$ RB, Rudd PM: Human serum IgM glycosylation: identification of glycoforms that can bind to mannan-binding lectin. J Biol Chem 2005, 280:29080-29087.

55. Sim RB, Day AJ, Moffatt BE, Fontaine M: Complement factor I and cofactors in control of complement system convertase enzymes. Meth Enzymol 1993, 223:13-35.

56. Laemmli UK: Cleavage of structural proteins during the assembly of the head of bacteriophage T4. Nature 1970, 15:680-685.

57. Fairbanks G, Stec TL, Wallach DF: Electrophoretic analysis of the major polypeptides of the human erythrocyte membrane. Biochemistry 1971, 10:2606-2617

58. Tan LA, Yu B, Sim FC, Kishore U, Sim RB: Complement activation by phospholipids: the interplay of factor $\mathrm{H}$ and C1q. Protein Cell 2010 1:1033-1049.

doi:10.1186/1746-6148-8-91

Cite this article as: Moreno-Indias et al:: The complement system of the goat: Haemolytic assays and isolation of major proteins. BMC Veterinary Research 2012 8:91. 